\title{
Resumptive anaforer. \\ En komparativ undersøgelse af en lidt overset sproglig størrelse
}

\section{Iørn Korzen}

Resumptive anaphors encapsulate and hypostatise a whole text segment. This survey compares and categorises Italian and Danish resumptive anaphors in a comparable subcorpus of the "Europarl Corpus" (political speeches held in the European Parliament). The anaphors are morphologically subdivided in NPs and pro-forms and the NP anaphors are semantically categorised in nominal derivatives and synonyms, generalising NPs, specifying NPs, axiological NPs, and performative NPs. With a pro-form anaphor, a similar categorisation of the anaphorised text segment is conveyed by the co-text, typically the predicate, of the anaphor. Pro-form anaphors are particularly frequent in Danish and NP anaphors in Italian, thus confirming the predominantly verbal style in Scandinavian and nominal style in Romance.

Nøgleord: anaforer, koreference, indkapsling, semantik, nominalstil, verbalstil

\section{Introduktion}

Resumptive anaforer er de anaforer der genoptager (resumerer, indkapsler) et helt tekstsegment: en tekstsekvens, en sætning eller en del af en sætning. Den genoptagede størrelse er således en "højereordensentitet", dvs. en entitet af højere orden end første i Lyons' og Diks terminologi. Som bekendt opererer Lyons (1977: 442-452) med entiteter af første orden (fysiske størrelser: individer og masser, som eksisterer i dimensionen rum), af anden orden (sagforhold: handlinger, aktiviteter og tilstande, som eksisterer i dimensionen tid) og af tredje orden (abstrakter: propositioner, begreber, matematiske ligninger o.l., som ligger uden for tid og rum). Hertil føjer Dik (1997: 223-228) entiteter af nulte orden (egenskaber eller relationer knyttet til størrelser) og af fjerde orden (talehandlinger). En resumptiv anafor genoptager således et sagforhold, et ab- 
straktum (typisk en eller flere propositioner) eller en talehandling, med andre ord en ikke-referentiel størrelse, der ved genoptagelsen hypostatiseres og gøres til en diskursreferent. Det betyder at vi ser bort fra anaforer der genoptager en i forvejen hypostatiseret diskursreferent med det nævnte semantiske indhold; her vil der være tale om en koreferentiel anafor, se et eksempel i (4) nedenfor. ${ }^{1}$

En resumptiv genoptagelse kan ske ved en anaforisk NP, som i (1), eller ved en anaforisk pro-form, som i (2):

(1) Der er ikke mere vin. Det problem må vi gøre noget ved.

(2) Der er ikke mere vin. Det er et stort problem.

Det er en anafortype der er lidt overset i den lingvistiske litteratur, ikke mindst i den danske, og der knytter sig mange uafklarede spørgsmål til den, fx disse:

a) Kan pronominer, jf. (2), overhovedet opfattes som resumptive anaforer, når de ikke har nogen leksikalsk intension?

b) Hvordan kan NP-anaforerne inddeles semantisk? Er det muligt at klassificere nominale indkapslinger i tekster?

c) Hvis a)-spørgsmålet kan besvares positivt, hvordan fordeler resumptive NP- og proform-anaforer sig så i typologisk forskellige sprog som fx de skandinaviske og de romanske, og hvorfor?

Nedenfor vil jeg - på basis af et dansk og italiensk parallelkorpus af tekster taget fra det såkaldte "Europarl Corpus", som består af de politiske taler holdt i Europaparlamentet (Koehn 2005, http://statmt.org/europarl/) - forsøge at nærme mig et svar på de tre spørgsmål. Mit danske og italienske korpus er stort set lige store, og de i alt 100 taler er udvalgt således at de er indbyrdes nogenlunde lige lange og repræsenterer en så stor variation som muligt af forfattere og politiske temaer:

1 Vi ser også bort fra den især angelsaksiske brug af termen "resumptive anaphors" brugt om pronominer der genoptager og "samler" mere end én førsteordensentitet; se fx McCloskey (2005) og Adger (2011). Ligeledes bortses fra adjektiver der sammenfatter en foregående tekst og bruges om en genoptaget førsteordensentitet; se herom fx D'Addio Colosimo (1990: 21ff). 


\begin{tabular}{|l|c|c|}
\cline { 2 - 3 } \multicolumn{1}{c|}{} & Danske & Italienske \\
\hline Antal EU-parlamentstaler (alle L1) & 50 & 50 \\
Samlet antal ord & 14.737 & 14.708 \\
\hline
\end{tabular}

Tabel 1. Europarl-korpus anvendt til undersagelsen

Mit indlæg har følgende disposition: Efter en kortfattet bibliografisk oversigt i afsnit 2 giver jeg en - ligeledes kortfattet - oversigt over de koreferentielle anaforer i afsnit 3. Derefter viser jeg, i afsnit $4 \mathrm{og}$ underafsnit, at de resumptive anafortyper kan opstilles og beskrives meget parallelt med de koreferentielle, og endelig sammenfatter jeg mønsteret og sammenligner danske og italienske forekomster i afsnit 5 .

\section{Kortfattet bibliografisk oversigt}

Fænomenet resumptiv (eller indkapslende) anafor er meget sparsomt undersøgt i og på dansk, hvorimod behandlingen er mere omfattende i den engelsk- og romansksprogede litteratur. Halliday \& Hasan (1976: 52-53, 66-67) taler mig bekendt som de første - om fænomenet, som de benævner "extended reference" og begrænser til pronominerne it, this, that. Krenn (1985: 212-224) inkluderer derimod, i en større undersøgelse, også NP'er med substantiver som thing, matter, point, question. I Italien introducerer D'Addio Colosimo (1984, 1988, 1990) termen "nominali incapsulatori anaforici" inspireret af den engelske term "encapsulation" foreslået af Sinclair (1982). ${ }^{2}$ Bortset fra en kort passus i 1988-artiklen (1988: 146), hvor de italienske pronominer questo, ciò ('dette', 'det') medtages blandt de resumptive anaforer, begrænser D'Addio Colosimo fænomenet til NP'er, hvilket også er tilfældet hos Simone (1990: 217-218, 436) og Conte (1998), (1999). Simone benævner - inspireret af Halliday \& Hasan - antecedenten "punto di attacco esteso" ("udvidet/udstrakt forbindelsespunkt'), og Conte sætter især fokus på resumptivernes tekststrukturerende funktion. Også Borreguero Zuloaga (2006: 80ff) begrænser resumptiver til NP'er og benævner pronominer med en tilsvarende funktion som "anáforas textuales" ('tekstanaforer'), jf. også Borreguero Zuloaga \& Toledo (2007). Men det er lidt svært at finde en helt klar teoretisk begrundelse for en terminologisk

2 "By referring to a preceding utterance with discourse labels like question or reply, a speaker or writer encapsulates the old interaction in his new one, and the discourse proceeds, in a sense, talking about itself." (Sinclair 1982: 76). 
distinktion mellem de to anafortyper hos forfatteren. Således anfører fx Lala (2010: 61) da også at de to anafortyper er "sproglige strategier" med præcis den samme tekstuelle funktion.

På italiensk grund er Pecorari (2015) mig bekendt den første der specifikt inkluderer pronominer blandt de resumptive anaforer, hvilket dog også var sket på dansk grund hos fx Dam (2003), Lundquist (2005: 149; 2007: 99) og Korzen (2000a: 145; 2000b: 582-588; 2007: 106; 2016). For så vidt angår NP-resumptiverne, er der ikke indtil nu - mig bekendt - foretaget forsøg på en samlet semantisk beskrivelse.

I det følgende vil jeg argumentere for at det, især i en komparativ sammenhæng, giver særdeles god mening at behandle resumptive pronomenanaforer sammen med NP-anaforer. Sammenligningerne går på to niveauer, dels sprogtypologisk, idet jeg sammenligner dansk og italiensk, dels anafortypologisk, idet jeg sammenligner de koreferentielle og de resumptive anaforer.

\section{De koreferentielle anaforer}

Når en anafor genoptager en diskursreferent, taler man om "koreference", idet der er tale om reference til samme diskursreferent i både antecedent og anafor. ${ }^{3}$ Anaformulighederne kan beskrives som i tabel 2:

\begin{tabular}{|c|c|c|c|}
\hline Antecedent $\mathrm{NP}_{1}$ & $\leftarrow$ & $\begin{array}{l}\text { Koreferentiel anafor pron./ } \varnothing \\
\text { eller } \mathrm{NP}_{2}\left[\mathrm{det}+\mathrm{N}_{2}\right]\end{array}$ & Anaforisk undertype \\
\hline \multirow{6}{*}{ En bil } & \multirow[b]{6}{*}{ L } & den, denne; ital.: questo, $10, \varnothing$ & Pronomen/ital.: nulsubjekt \\
\hline & & Bilen & "Tro" NP $\left(\mathrm{N}_{1}=\mathrm{N}_{2}\right)$ \\
\hline & & Automobilen & "Utro" NP $\left(\mathrm{N}_{1} \neq \mathrm{N}_{2}\right)$ : synonym \\
\hline & & Køretøjet & Utro NP: hyperonym \\
\hline & & Den Volvo & Utro NP: hyponym \\
\hline & & Den sardindåse & Utro NP: aksiologisk vurderende ${ }^{4}$ \\
\hline En udtalelse & $\leftarrow$ & Den indrømmelse & Utro NP: illokutionært vurderende ${ }^{5}$ \\
\hline
\end{tabular}

Tabel 2. De forskellige koreferentielle anafortyper (antecedenten er en diskursreferent)

3 Betimeligheden af termen "koreference" i sådanne tilfælde kan dog diskuteres, idet der er tale om to forskellige typer reference: én exoforisk fra antecedenten til diskursreferenten og én endoforisk fra anaforen til antecedenten, en reference som ikke går direkte til diskursreferenten; jf. Korzen (1996), (1998).

4 Dvs. æstetisk eller etisk positivt eller negativt.

5 Hermed mener jeg vurderende mht. talehandling. 
Når anaforen er en NP, er fortolkningen af anaforrelationen afhængig af accepten af prædikationen:

(3) $\quad \mathrm{NP}_{1}$ er en $\mathrm{N}_{2}\left(\mathrm{NP}_{1}=\right.$ antecedenten; $\mathrm{N}_{2}=\mathrm{N}$-kernen i anaforen + evt. udvidelse).

Men den utro relation udtrykt med et hyponym eller en aksiologisk eller illokutionært vurderende NP, de tre sidste muligheder i Tabel 2, kræver mere inferens fra modtagerens side, idet den præsupponerede prædikation her snarere hedder:

(3)' $\quad \mathrm{NP}_{1}$ kan vere en $\mathrm{N}_{2}\left(\mathrm{NP}_{1}=\right.$ antecedenten; $\mathrm{N}_{2}=\mathrm{N}$-kernen $\mathrm{i}$ anaforen + evt. udvidelse),

fx En bil kan vare en Volvo / en sardindåse osv. Denne yderligere inferens nødvendiggør den demonstrative artikel, der ekspliciterer at antecedenten skal findes i samme tekst (Korzen 2000b: 392ff; 2001), et fænomen jeg vender tilbage til nedenfor.

Ontologisk kan antecedenten være en første- eller højereordensentitet, men til forskel fra de resumptive relationer er der tekstfunktionsmæssigt altid tale om en diskursreferent. Et eksempel på en højereordens-diskursreferent fra mit korpus:

(4) Der er kun én logisk begrundelse for en ensartet lovgivning: onsket om at skabe en falles stat uden indre grenser. Det er denne tvangstanke om Europas granseløst forenede stater, som nu i praksis lægger også nyttigt internationalt samvirke for had. <ep-96-10-23.txt:28>. ${ }^{6}$

Da tvangstanke har en negativ ladning, bør dette eksempel nok placeres blandt de aksiologisk vurderende NP-anaforer. ${ }^{7}$

6 Henvisningerne til Europarl-teksterne ("ep") består af år-måned-dag efterfulgt af talernummer, "txt". I Europarl-eksemplerne angives antecedenterne i kursiv og anaforerne i fed kursiv.

7 De koreferentielle anaforer kan godt inddeles i finere semantiske og/eller pragmatiske undergrupper; se fx Korzen (1996: 523-540), (2000b: 512-534), (2001). 


\section{De resumptive anaforer}

De resumptive anaforer kan stilles op meget parallelt med de koreferentielle. Dog er antecedenten her et tekstsegment, TS, og ikke en diskursreferent, hvorfor man ikke kan tale om "koreference".

\begin{tabular}{|c|c|c|c|}
\hline Antecedent TS & $\leftarrow$ & $\begin{array}{l}\text { Resumptiv anafor pron./ } \varnothing \text { eller } \\
\text { NP [det }+N]\end{array}$ & Anaforisk undertype \\
\hline \multirow{6}{*}{$\begin{array}{l}\text { Ole og Pia har } \\
\text { besluttet at de } \\
\text { skal skilles. }\end{array}$} & [ & $\begin{array}{l}\text { Ole har selv sagt det. / } \varnothing \text { È triste. } \\
\text { 'Det er trist'. }\end{array}$ & Pronomen/ital.: nulsubjekt \\
\hline & & De traf beslutningen forleden. & NP-derivater og synonymer \\
\hline & & Situationen er meget trist. & Generaliserende NP \\
\hline & & Det udfald havde vi ikke forudset. & Specificerende NP \\
\hline & & At den ulykke skulle overgå dem. & Aksiologisk vurderende NP \\
\hline & L & Den meddelelse fik vi i går. & Illokutionært vurderende NP \\
\hline
\end{tabular}

Tabel 3. De forskellige resumptive anafortyper (antecedenten er et tekstsegment)

Termerne i højre kolonne er mine egne og fremstår i visse tilfælde som temmeligt vage, hvilket bl.a. afspejler at grænserne mellem de enkelte NP-typer, som vi skal se nedenfor, ikke er fuldstændig krystalklare; der er snarere tale om et semantisk kontinuum end om helt adskilte grupper. Dog er det med den anvendte taksonomi lykkedes ret nemt at placere alle de i alt 69 resumptive NP-anaforer i mit korpus.

Til gengæld kan det være sværere præcist at bestemme og afgrænse antecedenterne, hvilket jeg også skal vende tilbage til nedenfor. I de sidste fire tilfælde i tabel 3 kan man nok diskutere om antecedenten er hele den citerede TS eller måske alene den kompletive ledsætning.

Når indkapslingen er en NP, er anaforfortolkningen - parallelt med de koreferentielle anaforer - afhængig af prædikationen:

(5) TS er en $\mathrm{N}(\mathrm{TS}=$ antecedenten; $\mathrm{N}=\mathrm{N}$-kernen i anaforen + evt. udvidelse)

I de tre sidste NP-typer rummer kategoriseringen et større krav til fortolkning og inferens fra modtagers side, og den præsupponerede prædikation hedder snarere:

(5)' TS kan vare en $\mathrm{N}(\mathrm{TS}=$ antecedenten; $\mathrm{N}=\mathrm{N}-$ kernen i anaforen + evt. udvidelse), 
og helt parallelt med de koreferentielle anaforer - og med samme funktion som ved disse - finder vi normalt den demonstrative artikel i disse tilfælde.

Strengt taget er alle NP-indkapslingerne kategoriserende; de placerer antecedenten i en semantisk og/eller pragmatisk kategori, men de to første NP-typer, "NP-derivater og synonymer" (som beslutningen deriveret af har besluttet) og "Generaliserende NP'er" bidrager ikke med noget nyt, væsentligt semantisk indhold i ko-teksten. Førstnævnte type rummer dels morfologiske afledninger som har besluttet $\rightarrow$ beslutningen, dels andre eksempler på videreførelse af semiske elementer fra antecedenten, se afsnit 4.2.

I de følgende afsnit vil jeg citere en række eksempler på de forskellige typer fra mit korpus. Med en enkelt undtagelse er det danske eksempler; tilsvarende italienske eksempler kan ses i Korzen (2016).

\subsection{Pronomenanaforer og nulformer}

Pronomenanaforerne er særdeles hyppige, især i dansk, hvilket vi skal vende tilbage til i afsnit 5. Her optræder personlige pronominer, (6) det ${ }_{1}$, og demonstrative pronominer, (6) $\operatorname{det}_{2}$ og (7):

(6) ... går noget senere galt, fordi enten direktionen eller bestyrelsen foretager sig noget imod deres råd, så skal $\boldsymbol{d e t}_{\boldsymbol{1}}$ ikke medføre forøgede straffe. Jeg har forstået på kommissær Monti og hans medarbejdere, at $\boldsymbol{d e t}_{2}$ er et synspunkt, som han deler, ... <ep-01-09-05.txt:351>8

(7) Kun få falles regler og procedurer [for tredjelandsstatsborgeres indrejse og ophold $i$ EU] er galdende $i$ alle medlemsstaterne, og dette medfører, at der ikke eksisterer et legalt og administrativt værktøj, der kan bidrage til en bedre styring af migrationsstrømmene. <ep-03-02-11.txt:38>

I (6) er det ,'s antecedent den foregående betingelsesledsætning, hvorimod det ${ }_{2}^{\text {'s }}$ antecedent er hele den foregående sætning. Det bemærkes således (med det lille forbehold i fodnote 8) at demonstrativet benyttes ved den mest komplekse antecedent.

Indkapslingen har her rent tekstpragmatisk funktion: En proposition eller prædikation hypostatiseres og gøres til diskursreferent; der sker ingen kate-

8 Det kan muligvis diskuteres hvorvidt det $_{2}$ er et demonstrativ og ikke snarere et personligt pronomen

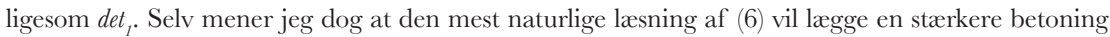
på $\operatorname{det}_{2}$ end på $\operatorname{det}_{1}$. 
gorisering af semantisk eller pragmatisk art. Nulformer forekommer på prodrop-sprog som italiensk, om end de ikke er meget hyppige som indkapslere, se fodnote 12:

(8) Vorrei sottolineare che più volte ... ho dovuto lamentare che le relazioni della commissione per la ricerca e l'energia finiscono per essere discusse in orari quantomeno particolari: o tardi nella serata o all'estremo limite della tornata. [Ø] È il caso anche oggi con questa importante relazione sulla panoramica della politica delle azioni energetiche. <ep-97-11-17.txt:24> (italiensk L1-tekst)

'Jeg vil gerne understrege, at jeg ... flere gange har måttet beklage mig over, at betenkningerne fra Forskningsudvalget ender med at blive forhandlet på lidt specielle tidspunkter: enten sent om aftenen eller allersidst i modeperioden. Dette er også tilfældet med denne meget vigtige betænkning om oversigten over energipolitikken.'

Oversættelsen til dansk er min egen, men er i alt væsentligt identisk med den officielle oversættelse fra Europaparlamentet. Det bemærkes således at det italienske nulsubjekt er oversat med et demonstrativt pronomen (som citeret) i den officielle danske oversættelse. Dette vender jeg tilbage til afsnit 5.

\subsection{NP-derivater og synonymer}

Disse anafortyper minder om hhv. den "tro" og den synonymiske koreferentielle anafor pga. gentagelsen af semiske elementer fra antecedenten. I (9)-(10) er der tale om derivater, og jeg har understreget de leksikalske elementer der videreføres i anaforerne:

(9) Havela er et lukket hemmeligt verdensomspændende netværk, der inden for et døgn kan overfore store beløb til alle steder $i$ verden. Overforslerne sker uden bilag og kan derfor aldrig spores. <ep-01-07-05.txt:33>

(10) Denne politiopbygning drejer sig på en gang om bevidstløs EUintegration og om at sikre Fort Europa. Denne sikring er en indlysende følge af det pres udefra, der skyldes misforholdet mellem EU-landenes velstand og naboernes sociale elendighed. <ep-03-01-13.txt:129>

At anaforerne ikke tilføjer ny tekstuel information, ses tydeligt i at man i (9) kunne have haft den leksikalsk tomme pronomenanafor det; i (10) ville det give risiko for fejlfortolkning. 
I (11) kan man tale om "semantisk isotopi" eller "leksikalsk kohærens" i betydningen sammenfald eller gentagelse af semer eller semantiske felter, jf. fx Frandsen (1988) og Gettrup et al. (1986):

(11) Flere og flere mennesker rundt omkring i Europa tror, at Kommissionen er et lukket system, som nægter at rette sig efter omverdenen og borgernes krav. At det er et gigantisk bureaukrati, hwor den ene del af embedsmandene snyder og bedrager, medens den anden del skal forsøge at dække over ulovlighederne. <ep-98-02-16.txt:20>9

\subsection{Generaliserende anaforer}

Denne type minder om de hyperonyme koreferentielle anaforer. De hhv. danske og italienske substantivkerner jeg er stødt på i mit korpus, er disse:

ting, forhold, sag, sammenhang, situation, tilfalde, tilstand (denne tingenes tilstand), område;

cosa ('ting'), fatto ('handelse'), caso ('tilfalde'), condizione ('tilstand'), punto ('punkt'), dati ('data'), tema ('emne').

Ofte er der tale om meget lange antecedentsammenhænge, og det kan være svært at afgrænse antecedentsegmentet helt præcist. ${ }^{10}$

... men forslagets og Kommissionens meddelelse fär betydning i lyset af en rakke andre vedtagelser om udbygning af politisamarbejdet. I denne sammenhang betegner forslaget en udvikling, der i mine øjne truer den demokratiske kontrol og retssikkerheden. <ep-03-01-13.txt:129>

... og dette medfører, at der ikke eksisterer et legalt og administrativt verktoj, der kan bidrage til en bedre styring af migrationsstrommene. Forslaget vil rette op på denne situation. <ep-03-02-11.txt:38>

Selvom alle anafor-kernerne i (12) og (13) er meget generiske, dvs. har lille intension og stor ekstension, kan man nok tale om en vis "skala" fra ting, som

9 Denne anafortype beskrives af D'Addio Colosimo (1988: 148) som "direttamente ricavabile", dvs. direkte udledelig af antecedenten. Man kan nok diskutere om der ikke, i ulovlighederne, snarere er tale om et hyperonym end om et synonym, men typen adskiller sig dog fra den generaliserende type i afsnit 4.3 .

10 Dette problem er velkendt ved resumptiverne og bl.a. omtalt af D'Addio Colosimo (1988: 144); Conte (1998: 153), (1999: 108); Lundquist (2009: 393); Lala (2010: 66). 
er omtrent betydningsløst (substantivet har stort set intet intensionelt indhold og ligger derved tættest på et pronomen), til område og emne, som måske har den relativt største intension.

\subsection{Specificerende anaforer}

Også blandt de specificerende resumptiver kan man tale om gradvist større og større intension, og en meget præcis afgrænsning til de generaliserende NP'er kan være vanskelig. De hhv. danske og italienske NP'er jeg er stødt på, er disse:

baggrund, retning, ide, erfaring, procedure, proces;

aspetto ('synspunkt'), direzione ('retning'), motivo ('motiv'), obiettivo / scopo ('formål'), presa di posizione ('stillingtagen'), punto di vista ('synspunkt'), ragione ('arsag'), senso ('betydning'), strategia ('strategi').

Et par danske eksempler:

(18) I mange år har opløsningsmidler været under mistanke for at føre til hjerneskader. Det er ... set i udstrakt grad hos malere, der er i daglig kontakt med stofferne. Herfra stammer begrebet smalersyndrometu. Disse erfaringer bør være med i dette direktiv, som vi behandler i dag, ... <ep-98-0113.txt:232>

(19) Det var 1996-regnskabet, der faldede den tidligere Kommission, og 1997-regnskabet er nojagtigt lige så belastende. Der er ingen grund til, at vi på den baggrund skulle acceptere at give decharge. <ep-00-01-18.txt:255>

Her skal modtager således, jf. (5)', inferere at det anaforiserede tekstsegment kan have den funktion som anaforen udtrykker, i relation til anaforens kotekst, en fortolkning som får visse forskere, fx Conte (1999: 110), til at tale om en pragmatisk indkapsling. Det er den anafortype der tydeligst afhænger af teksttypen; man kan tale om tekstens "leksikalske kerner", ${ }_{11}^{11}$ og anaforerne i (16)-(17) vidner klart om argumentative formål med teksterne.

I modsætning til de ovenfor omtalte anafortyper sker der her tydeligvis noget mere end blot en hypostatisering og funktionsændring til diskursreferent. Her sker også en klar semantisk-pragmatisk fortolkning af det anaforiserede i relation til den følgende ko-tekst, og anaforen danner derved overgangen

11 Cfr. Lundquist (2009: 389ff), som tilsvarende har undersøgt en sproglig, en økonomisk og en lægevidenskabelig tekst. 
til det næste tekstsegment og fungerer som et særligt struktureringselement, et tekstkohæsionselement.

\subsection{Vurderende anaforer}

Både blandt koreferentielle og resumptive anaforer kan der være tale om to forskellige slags vurdering eller "værdisætning", hhv. en aksiologisk og en illokutionær (jf. fodnote 4 og 5). Disse anaforer kan derfor kaldes pragmatiske i en lidt snævrere betydning af ordet end ved de specificerende anaforer. De er ikke meget hyppige i mit korpus, der teksttypemæssigt må kaldes argumentativt (jf. det foregående afsnit):

(20) Baggrunden for princippet om at bruge afsenderlandets regler er, at det er for besværligt for erhvervslivet at have kendskab til samtlige medlemslandes lovgioninger på området. Men konsekvensen er, at denne byrde blot lægges på forbrugernes skuldre. <ep-99-05-06.txt:42>

(21) Men selvfølgelig må vi spørge os selv, om snittet er lagt rigtigt, og om vi får nok for pengene, og det er selvfølgelig også en opgave for os som parlamentarikere at stille dette spørgsmål hele tiden. <ep-96-12-11. txt:268>

I (20) er der tale om en aksiologisk vurdering og i (21) om en illokutionær. Det kan tilføjes at eks. (21) ligger tæt på gruppen af NP-derivater, afsnit 4.2, med henvisning til at verbet spørge forekommer i den foregående ko-tekst; dog er forskellen den at dette verbum ikke er en del af antecedenten i (21), mens de tilsvarende verber var en del af antecedenterne til NP-derivaterne i afsnit 4.2.

De to slags værdisætning kan kombineres:

(22) Vejen til helvede er brolagt med gode forsatter. Jeg er ikke klar over, om dette udmarkede og laererige ordsprog også findes på de øvrige ti officielle sprog. Det findes i hvert fald på dansk, .. < ep-99-03-10. txt:31>

\section{Sammenfatning og lidt statistik}

Det er nok mest rigtigt at sige at de resumptive anaforer fordeler sig i "klumper" på et semantisk kontinuum, der kan beskrives som i tabel 4, snarere end i klart afgrænselige grupper. 


\begin{tabular}{|l|c|c|c|c|c|}
\hline $\begin{array}{l}\text { Resumptiv } \\
\text { anafortype }\end{array}$ & $\begin{array}{c}1 \\
\text { proformer }\end{array}$ & $\begin{array}{c}2 \\
\text { NP-derivater og } \\
\text { synonymer }\end{array}$ & $\begin{array}{c}\text { Generaliserende } \\
\text { NP'er }\end{array}$ & $\begin{array}{c}4 \\
\text { Specificerende } \\
\text { NP'er }\end{array}$ & $\begin{array}{c}5 \\
\text { Vurderende } \\
\text { NP'er }\end{array}$ \\
\hline \multirow{2}{*}{$\begin{array}{l}\text { Leksikalsk } \\
\text { information }\end{array}$} & ingen & $\begin{array}{c}\text { ko-tekstuelt } \\
\text { given }\end{array}$ & ny men vag & $\begin{array}{c}\text { mere præcis: “lek- } \\
\text { sikalske kerner" }\end{array}$ & $\begin{array}{c}\text { pragmatisk } \\
\text { indhold }\end{array}$ \\
\cline { 2 - 6 }
\end{tabular}

Tabel 4. Resumptive anaforer og informationsstruktur

Tekstpragmatisk sker der i samtlige tilfælde en hypostatisering af et foregående tekstsegment, som gøres til en diskursreferent, og i alle NP-typerne - men ikke i proform-typerne - sker der også en leksikalsk og evt. pragmatisk kategorisering. Alligevel har de forskellige NP-typer tekstinformationsmæssigt, dvs. informationsstrukturelt på det givne sted i ko-teksten, forskellige funktioner. I type 2 og 3 er den tekstpragmatiske funktion (hypostatisering og etablering af diskursreferent) den vigtigste (i type 1 er det den eneste). I type 4 og 5 spiller det leksikalske/pragmatiske indhold en større rolle; her er der tale om typer der kræver en særlig inferens, en inferens som i type 4 kan kaldes værdineutral (om end den spiller en stor rolle for tekststruktureringen) og i type 5 i højere grad pragmatisk og enten aksiologisk eller illokutionært vurderende. Type 4 er den der er mest teksttypespecifik; den indeholder tekstens "leksikalske kerner" og varierer mest fra teksttype til teksttype.

En statistisk inter- og intralingvistisk sammenligning af de forskellige anaforforekomster giver interessante resultater.

\begin{tabular}{|l|c|c|c|c|}
\hline \multirow{2}{*}{ Resumptive anaforer } & \multicolumn{2}{|c|}{ Antal forekomster } & \multicolumn{2}{c|}{ Heraf med demonstrativ } \\
\cline { 2 - 5 } & Dansk & Italiensk & Dansk & Italiensk \\
\hline Resumptive anaforer i alt & 133 & 97 & $101=75,9 \%$ & $81=83,5 \%$ \\
\hline - 1. Proformer i alt (pron. / ital. nulsubj.) & 103 & 58 & $77=74,8 \%$ & $48=82,8 \%{ }^{12}$ \\
\hline - NP-typer i alt & 30 & 39 & $24=80 \%$ & $33=84,6 \%$ \\
\hdashline 2. NP-derivater og synonymer & 6 & 6 & $2=33,3 \%$ & $3=50 \%$ \\
\hline 3. Generaliserende NP & 12 & 12 & $10=83,3 \%$ & $9=75 \%$ \\
\hline 4. Specificerende NP & 7 & 18 & $7=100 \%$ & $18=100 \%$ \\
\hline 5. Aksiologisk vurderende NP & 3 & 2 & $3=100 \%$ & $2=100 \%$ \\
\hline 5. Illokutionært vurderende NP & 2 & 1 & $2=100 \%$ & $1=100 \%$ \\
\hline
\end{tabular}

Tabel 5. Resumptive anaforer. Forekomster og former $i$ korpus

12 De 10 tilfælde der ikke er udfyldt med et demonstrativt pronomen, fordeler sig med 7 personlige pronominer og 3 nulsubjekter; se et eksempel på sidstnævnte i (8). 
Det højere samlede antal resumptive anaforer i det danske korpus - og ikke mindst det væsentligt højere antal proformer - kan bl.a. tilskrives det højere antal perioder, jf. tabel $6 .{ }^{13}$

\begin{tabular}{|l|c|c|}
\hline De to undersøgte korpora & Dansk & Italiensk \\
\hline Antal perioder & 678 & 440 \\
\hline
\end{tabular}

Tabel 6. Periodeantal $i$ de to undersogte korpora

Når information spredes over flere perioder, kræver det genoptagelse af flere (typisk leksikalsk indholdsløse) anaforer, der ikke har anden funktion end at føre diskursen videre.

Når den resumptive anafor er et pronomen, ligger en evt. kategorisering af det anaforiserede tekstsegment typisk i prædikationen knyttet til dette pronomen, hvilket vi så $\mathrm{i}$

\section{(2a) Det er et stort problem}

(6a) Jeg har forstået på kommissær Monti og hans medarbejdere, at det er et synspunkt, som han deler.

Når den resumptive anafor er en NP, ligger kategoriseringen og dermed en (potentielt) ny information derimod i denne NP. Derfor er den store forskel i fordelingen mellem proformer og NP'er i de to sprog interessant. I italiensk udgør NP-anaforerne 39 ud af i alt 97, dvs. 40,2 \%, i dansk 30 ud af $i$ alt 133, dvs. kun 22,6\%. Den officielle italienske oversættelse af (6a) lyder:

(6a)' Ho capito dal Commissario Monti e dai suoi collaboratori che egli è d'accordo con questo punto di vista.

'Jeg har forstået på kommissær Monti og hans medarbejdere, at han er enig i dette synspunkt.'

På denne måde undgås en finit sætning i den italienske version, og fænomenet bliver et eksempel på forskellen mellem den skandinaviske verbalstil og den romanske nominalstil, som også manifesterer sig ved den højere forekomst af

13 Som det fremgik af tabel 1, er ordantallet i de to korpora stort set det samme, så den store forskel i antallet af perioder giver også en stor forskel i gennemsnitlig periodelængde målt som antal ord pr. periode. Se herom Korzen (2015). 
propositioner tekstualiseret med infinitte eller nominaliserede verbalformer i romansk end i skandinavisk, jf. også Korzen (2015: 161-162).

Sådanne sprogtypologiske sammenligninger, der kan ses i relation til og som bekræftelse af andre typologiske forskelle i tekststruktur, er afhængige af en behandling af resumptive NP- og proform-anaforer i samme forbindelse og er derfor - efter min mening - et vældig godt argument for at inkludere proformer blandt andre resumptive anaforer.

Der er en nøje sammenhæng mellem den lingvistiske kodning af anaforen og anaforrelationens kompleksitet: Jo større kompleksitet, desto mere sproglig kodning; jf. Korzen (2015). Derfor er det interessant at se på demonstrativernes andel af de resumptive anaforer. Som sagt ekspliciterer et demonstrativ, både som pronomen og som artikel, at antecedenten er at finde i samme tekst, og i Korzen (2015) viste jeg at man på den baggrund (ikke overraskende) kan opfatte resumptiverne som mere komplicerede relationer end andre anaforrelationer. Herudover ser vi på begge sprog at de tre sidste anafortyper i tabel 5 har $100 \%$ forekomst af demonstrative artikler - helt parallelt med de tilsvarende typer blandt de koreferentielle anaforer, jf. tabel 2. Alle disse typer kræver mere inferens fra modtagers side.

Endelig er der generelt tale om højere demonstrativprocenter i italiensk end i dansk, hvilket jeg igen vil tilskrive den generelt større syntaktiske kompleksitet $\mathrm{i}$ italiensk end i dansk. (Den eneste undtagelse ses ved de generaliserende resumptiv-NP'er, men den konkrete forskel består her i én enkelt forekomst). Af samme grund er det næppe tilfældigt at den officielle danske oversættelse af den italienske tale i (8) har benyttet et demonstrativt pronomen til anaforiseringen af den temmelig komplekse antecedent.

Ser vi på antallet af forekomster af NP-typerne, ligger de to sprog meget tæt på hinanden - med den ene undtagelse i type 4, de "specificerende" resumptiver. Det er interessant at netop den indkapsling som formidler "teksttypekernerne" og derved klarest afslører teksttypen, samtidig med at den fungerer som et særligt tekststruktureringselement med en stærk kohæsionsfunktion, er væsentlig hyppigere $\mathrm{i}$ italiensk, hvor der generelt i det skolastiske system er umådelig stort fokus på tekstform, tekstkohæsion og tekststruktur. 


\section{Henvisninger}

Adger, D. (2011). Bare resumptives, i A. Rouveret (red.) Resumptive Pronouns at the Interfaces, Amsterdam/Philadelphia: John Benjamins, 343-366.

Borreguero Zuloaga, M. (2006). Naturaleza y función de los encapsuladores en los textos informativamente densos (la noticia periodística), Cuadernos de Filología Italiana 13, 73-95.

Borreguero Zuloaga, M. \& A. de Toledo (2007). Presencia y función de los encapsuladores en las crónicas periodísticas del s. XVII, Philologia Hispalensis 21, 119-153.

Conte, M.-E. (1998). Il ruolo dei termini astratti nei testi, i G. Bernini, P. Cuzzolin \& P. Molinelli (red.) Ars linguistica. Studi offerti a Paolo Ramat in occasione del $60^{\circ}$ compleanno, Roma: Bulzoni, 151-160.

Conte, M.-E. (1999). Anaphoric encapsulation, i M.-E. Conte (red.) Condizioni di coerenza. Ricerche di linguistica testuale. Nuova edizione con l'aggiunta di due saggi a cura di Bice Mortara Garavelli, Alessandria: Edizioni dell'Orso, 107-114.

D’Addio Colosimo, W. (1984). I nominali incapsulatori anaforici. Un aspetto della coesione lessicale, Rassegna Italiana di Linguistica Applicata 2 (3), 35-43.

D'Addio Colosimo, W. (1988). Nominali anaforici incapsulatori: un aspetto della coesione lessicale, i T. De Mauro, S. Gensini \& M.E. Piemontese (red.) Dalla parte del ricevente. Percezione, comprensione, interpretazione. Atti del XIX congresso internazionale di studi della SLI - Società di Linguistica Italiana (Roma, 1985), Roma: Bulzoni, 143-151.

D'Addio Colosimo, W. (1990). Tra capsule anaforiche e sinonimi contestuali. Aspetti testuali del lessico, LIS, Linguistica selecta. Pubblicazioni del Dipartimento di Scienze del Linguaggio dell'Università di Roma "La Sapienza" 1, 6-32.

Dam, L. (2003). Indkapsling i spansk, i B.L. Jensen, I. Korzen \& H.H. Müller (red.) Ny forskning i grammatik. Fallespublikation 11, Odense: Syddansk Universitetsforlag, 83-101.

Dik, S.C. (1997). The Theory of Functional Grammar. Part II: Complex and Derived Structures. Functional Grammar Series 21, ed. by K. Hengeveld, Berlin-New York: Mouton de Gruyter.

Frandsen, F. (1988). Semantisk isotopi og diskursanalyse, Hermes 1: 45-62.

Gettrup, H., et al. (1986). Sprog $\&$ tekst. Studiebog i sagtekstanalyse. København: Københavns Universitet, Romansk Institut.

Halliday, M.A.K. \& R. Hasan (1976). Cohesion in English. London: Longman. Koehn, P. (2005). Europarl: A parallel corpus for statistical machine translation. Conference Proceedings: the tenth Machine Translation Summit, Phuket, Thailand, 79-86. 
Korzen, I. (1996). L'articolo italiano fra concetto ed entità. Vol. I-II. København: Museum Tusculanum Press.

Korzen, I. (1998). On nominal determination - with special reference to Italian and comparisons with Danish, i G. Hansen (red.) Nominal Determination. Copenhagen Studies in Language 21, 67-132.

Korzen, I. (2000a). Spørgsmål-svar som tekstsekvens, i G. Skytte \& I. Korzen. Italiensk-dansk sprogbrug $i$ komparativt perspektiv. Reference, konnexion og diskursmarkering, København: Samfundslitteratur, 123-152.

Korzen, I. (2000b). Reference og andre sproglige relationer, i G. Skytte \& I. Korzen. Italiensk-dansk sprogbrug $i$ komparativt perspektiv. Reference, konnexion og diskursmarkering, København: Samfundslitteratur, 161-619.

Korzen, I. (2001). Anafore e relazioni anaforiche. Un approccio pragmaticocognitivo, Lingua nostra LXII (3-4), 107-126.

Korzen, I. (2007). Linguistic typology, text structure and anaphors, i I. Korzen \& L. Lundquist (red.) Comparing Anaphors. Between Sentences, Texts and Languages, Copenhagen Studies in Language 34, 93-109.

Korzen, I. (2015). Sprogtypologi og anaforer. Om anaforrelationer i endo- og exocentriske sprog, i S.E. Bentsen, et al. (red.) Ny forskning i grammatik 22, Frederiksberg: Dansk Sprognævn, 149-165.

Korzen, I. (2016). Come riassumere un messaggio politico? Strategie e strutture di incapsulazione anaforica nei discorsi del Parlamento Europeo, i G. Ruffino \& M. Castiglione (red.) La lingua variabile nei testi letterari, artistici e funzionali contemporanei. Analisi, interpretazione, traduzione, Firenze: Franco Cesati, 443-459.

Krenn, M. (1985). Probleme der Diskursanalyse im Englischen. Verweise mit this, that, it und Verwandtes. Tübingen: Gunter Narr, 1985.

Lala, L. (2010). L'incapsulatore anaforico cosa nell'orale e nello scritto, i A. Ferrari \& A.-M. De Cesare (red.) Il parlato nella scrittura italiana odierna, Bern: Peter Lang, 57-78.

Lundquist, L. (2005). Tekst, i I. Korzen \& L. Lundquist (red.) Sprogtypologi og oversattelse. Endocentriske og exocentriske sprog, København: Handelshøjskolen i København, 140-153.

Lundquist, L. (2007). L'anaphore lexicale démonstrative dans les langues endo- et exocentriques: langue, texte, discours, i I. Korzen, M. Lammert \& H. Vassiliadou (red.) Langues d'Europe, l'Europe des langues. Croisements linguistiques, Scolia 22, 85-104.

Lundquist, L. (2009). L'anaphore resomptive. Navigation textuelle et comparaison discursive, i F. Venier (red.) Tra pragmatica e linguistica testuale: ricordando Maria-Elisabeth Conte, Alessandria: Edizioni dell'Orso, 379-399. 
Lyons, J. (1977). Semantics, 1-2. Cambridge: Cambridge University Press. McCloskey,J. (2005). Resumption, i M. Everaert \& H. van Riemsdijk (red.) The Blackwell Companion to Syntax. Vol. IV. Oxford: Blackwell, 2005. Blackwell Reference Online. http://www.blackwellreference.com.esc-web.lib.cbs.dk/subscriber/tocnode.html?id=g9781405114851_chunk_g978140511485158, fundet 2. oktober 2015.

Pecorari, F. (2015). La coesione testuale dei lanci di agenzia. Uno studio delle anafore di ordine superiore. Revue Romane 50:2, 222-278.

Simone. R. (1990). Fondamenti di linguistica. Roma-Bari: Laterza.

Sinclair, J. (1982). Planes of discourse, i S.N.A. Rizvi (red.) The Two-fold Voice. Essays in Honour of Ramesh Mohan, Salzburg: Institut für Anglistik und Amerikanistik, Universität Salzburg, 70-91. 